\title{
Areas of endemism in the Atlantic Forest: quantitative biogeography insights from orchid bees (Apidae: Euglossini)
}

\author{
André R.S. GARRAFFONI ${ }^{1,2}$, Filipe R. Moura ${ }^{2}$, Anete P. LOUREnÇO ${ }^{2}$ \\ ${ }^{1}$ Present address: Departamento de Biologia Animal, Instituto de Biologia, Universidade Estadual de Campinas, \\ Campinas, SP, Brazil \\ ${ }^{2}$ Departamento de Ciências Biológicas, Universidade Federal dos Vales do Jequitinhonha e Mucuri, Diamantina, MG, \\ Brazil
}

Received 27 March 2016 - Revised 9 January 2017 - Accepted 16 January 2017

\begin{abstract}
Orchid bees are endemic to the Neotropics and were sampled more intensively in the Atlantic Forest in the last decade than in that of other Brazilian biomes. In this study, we aimed at identifying the main distributional patterns and areas of endemism of Euglossini orchid bee species in the Atlantic Forest using parsimony analysis of endemism and endemicity analysis. The results of these analyses were partly congruent and supported the idea that the distribution of orchid bees is structured into at least five areas of endemism: Pernambuco/coastal Bahia; Espírito Santo/Rio de Janeiro/south of Minas Gerais; north of Minas Gerais/central Bahia; southeast of Minas Gerais/ northeast, central and coast of São Paulo/central and coastal Paraná; and central/coast of Santa Catarina-Rio Grande do Sul. Most of these areas were consistent with other groups of organisms and indicate the existence of real areas of endemism in the Atlantic Rain Forest.
\end{abstract}

distribution pattern / insects / PAE / NDM / orchid bees

\section{INTRODUCTION}

Biogeography investigates the history of organisms in space using comparative biology as a background (Morrone 1994). This discipline involves the following two primary stages: inference associated with the primary biogeographic homology based on a common history, which is conjectured by identifying areas of endemism

Electronic supplementary material The online version of this article (doi:10.1007/s13592-017-0494-6) contains supplementary material, which is available to authorized users.

Corresponding author: A. Garraffoni,

arsg@unicamp.br

Manuscript editor: Marina Meixner

In order to explain the content of the Suppl. Materials, these legends must be included in the article: either here or in an Annex (or Appendix) at the end of the article (please see what I suggest in the attached file). (non-random distributional congruence among distinct taxa-Morrone 1994) or generalized tracks; and cladistic testing of the previously hypothesized homology, to find the secondary biogeographic homology (Morrone 2001, 2014).

The most common methods for inferring the primary biogeographic homology are the parsimony analysis of endemicity (PAE) and endemicity analysis (NDM) (Morrone 1994, 2014; Szumik et al. 2002; Szumik and Goloboff 2004; Nihei 2006). PAE and NDM use biota similarity to elucidate faunal distribution patterns. Based on species presence-absence data matrices, PAE treats geographic areas as lines (i.e., taxa) in a traditional data matrix and taxa distribution as characters, similar to a cladistic analysis (Nihei 2006; Morrone 2014). NDM identifies areas of endemism by applying an optimality criterion to evaluate congruence among species distributions, using the endemicity index, to reveal distributional patterns (Szumik et al. 2002; 
Szumik and Goloboff 2004; Ferrari et al. 2010; Carvalho 2011; Casagranda et al. 2012). Based on the adjustment of species distribution to the analyzed grid, NDM uses an optimality criterion to assign an endemicity score to a given area (Escalante et al. 2013). Both PAE and NDM are used to delineate areas of endemism, using gridcells as operational units without inferring relationships or hierarchies between the areas.

The Atlantic Rain Forest is distributed along most of the Brazilian coast, having originally occupied approximately $15 \%$ of the Brazilian territory. However, the forest has become completely fragmented, now covering less than $8 \%$ of its original area (Morellato and Haddad 2000). The Atlantic Forest biome shows great environmental complexity and can support high levels of diversity and endemism (Nemésio 2009; DaSilva and Pinto-da-Rocha 2011).

Although orchid bees (Apidae: Euglossini) now range from the southern USA to southern Brazil and northern Argentina (Nemésio 2009), they are a well-known taxon in the Atlantic Forest resulting in numerous sampling sites and a wellestablished taxonomy (Nemésio 2009; Nemésio and Vasconcelos 2013). Five genera have been recognized in the classification of Euglossini: Euglossa Latreille 1802, Eufriesea Cockerell 1908, Eulaema Lepeletier 1841, Exaerete Hoffmannsegg 1817, and Aglae Lepeletier and Serville 1825 , collectively encompassing more than 250 species (Roubik and Hanson 2004; Michener 2007; Nemésio 2009). Orchid bees are commonly known for their metallic hues (different shades of green, blue, violet, and red), medium to large body size ( 8 to $30 \mathrm{~mm}$ ), and corbiculae (Silveira et al. 2002; Michener 2007; Nemésio 2009).

This study aimed at identifying areas of endemism in the Atlantic Forest characterized by distributional patterns of orchid bees by means gridcell analyses (PAE and NDM). Furthermore, it also complements previous studies that analyzed the spatial distribution patterns of orchid bees along the different subregions of the Neotropics (not only the Atlantic Forest) using ordination procedures to describe the groups of assemblages according to occurrences of euglossine bees (Nemésio and Silveira 2007; Sydney et al. 2010).

\section{MATERIALS AND METHODS}

Distribution data on orchid bees in the Atlantic Forest were compiled from the literature (see supplementary material S1 for references). We recorded 1630 points of occurrence of Euglossini. Taxonomic decisions were based on Moure's Bee Catalogue (Moure et al. 2012). The taxa analyzed were represented by 66 Euglossini species, belonging to Euglossa (45 spp.), Eufriesea (7 spp.), Eulaema (10 spp.), and Exaerete (4 spp.) (supplementary material S2). As all genera in Euglossini used in the present study have the initial "E", we used the following abbreviations: $E g$. for Euglossa; Ef. for Eufriesea; El. for Eulaema; and Ex. for Exaerete.

\subsection{Parsimony analysis of endemicity}

This method was originally developed and implemented by Rosen (1988) and Rosen and Smith (1988) and can be used both statically and dynamically (Nihei 2006). Static PAE, which was applied here, cannot prove or reveal any information about processes and is applied to a biota situated within a single geologic age (present), whereas, dynamic PAE is applied to biota from two or more separate geological ages (Nihei 2006).

Grid-cells are a decisive component in biogeographic analyses (Morrone and Escalante 2002; Contreras-Medina et al. 2007); therefore, the PAE analysis of the entire Atlantic Forest domain was divided into grid-cells of two different sizes, $1 \times 1^{\circ}$ and $3 \times 3^{\circ}$. Applying grid-cells of different sizes to a single data set makes it possible to obtain results that are more complete because different quadrant sizes can be sensitive to different distributional patterns within the same geographic region (the use of small grid-cells can produce poorly resolved area cladograms) (Morrone and Escalante 2002; Contreras-Medina et al. 2007). In addition, a study area may contain different levels of endemism in different regions (DaSilva 2008).

We only considered an area of the endemism when the relationship between the grid-cells was supported by the occurrence of two or more exclusive species ("synapomorphic species").

Parsimony analysis was carried out using the TNT software (Goloboff et al. 2003, 2008). A traditional search was executed using 1,000,000 
replicates and with a tree bisection and reconnection swapping algorithm with five trees saved per replicate. The saved trees were analyzed using Winclada (Nixon 2002). Strict consensus was used to summarize the information obtained from the most parsimonious cladograms.

\subsection{Endemicity analysis}

NDM was originally proposed by Szumik et al. (2002) and Szumik and Goloboff (2004) and was implemented as a computer program by Goloboff (2005). We used the computer program NDM/ VNDM 2.5 (Goloboff 2005) to test two distinct grids, with grid-cells of $1 \times 1^{\circ}$ and $3 \times 3^{\circ}$, performing 100 random additional sequences. We grouped the initial areas that included a certain number of endemic species and then applied a flexible consensus with $40 \%$ minimum similarity of endemic species (Ferrari et al. 2010). A default score of 2.00 was used to define the groups of cells that would qualify as areas of endemism.

\section{RESULTS}

None of the 66 orchid bee species were widespread within the forest. The distributional ranges of orchid bees vary widely, with some species spanning nearly $20^{\circ}$ of latitude (e.g., Eg . cordata, El . nigrita $23^{\circ} ;$ Ef. auriceps $20^{\circ} ;$ Eg . viridis, El . cingulata, Ex. smaragdina $18^{\circ} ;$ Eg . crassipunctata, Eg . fimbriata, and Eg. truncata $\left.17^{\circ}\right)$ and others spanning less than $3^{\circ}(E g$. nanomelanotricha, El. seabrai $3^{\circ} ; \mathrm{Eg}$. anodorhynchi, Eg. heterosticta, Eg . pepei, Eg . solangeae, Ex. salsai $2^{\circ}$; and Eg. iopyrrha, El. helvola $1^{\circ}$ ) (supplementary materials S3 and S4).

The number of areas (grid-cells) varied according to PAE quadrat size, i.e., either 92 grid-cells of $1 \times 1^{\circ}$ or 28 grid-cells of $3 \times 3^{\circ}$ (Figure 1a-b). For the 1 degree quadrat matrix, we obtained 26 cladograms of 329 steps. Strict consensus (supplementary material S5) revealed a basal polytomy for 40 quadrats, whereas the 52 remaining quadrats were grouped into 5 major clades (Figure 1a). As we considered that an endemism area should have at least two species, and only the following clade supported areas of endemism: northern coast of Espírito Santo, south and southeastern coast of Bahia state, and coast of
Alagoas and Pernambuco (areas 7, 8, 14, 15, 16, 17, 18,20 , and 27), which shared the synapomorphic species Eg. mixta and Eg. milenae.

The PAE using a 3-degree quadrat matrix resulted in 45 cladograms with 170 steps. Strict consensus (supplementary material S6) indicated only one trichotomy among the 28 areas and at least two major clades were observed (Figure 1b). In this case, the following two areas of endemism were observed: one major area including the coasts of Paraíba, Pernambuco, Alagoas states, the south and southeast coast of Bahia state and the northern coast of Espírito Santo (areas 3, 7, 8, and 9) that shared the synapomorphic species $E g$. adiastola, Eg. amazonica, Eg . calycina, Eg . milenae, and Eg . monnei; the subclade including the south and southeast coast of Bahia state and the northern coast of Espírito Santo (areas 7, 8, and 9) that shared the synapomorphic species $E g$. avicula and Eg. liopoda .

Based on the 1-degree grid, our NDM identified eight areas of endemism with endemism scores ranging from 2.16 to 5.31. The consensus analysis identified four clusters of grid-cells with endemism scores ranging from 2.02 to 5.31 (some endemic areas partially overlapped in each cluster) (Figure 2a-d, Table I). This approach revealed two areas of endemism concentrated in the Atlantic Forest in northeast Brazil with disjunct distribution (coastal Bahia-Espírito Santo and Pernambuco areas). The endemicity analysis of 3-degree gridcells identified 44 endemic areas with endemism scores ranging from 2.12 to 13.83 . The consensus analysis summarized three clusters of grid-cells with endemism scores ranging from 2.12 to 14.08 (some endemic areas partially overlapped in each cluster) (Figure 2e-f, Table I). In two grid-cells (Figure $2 \mathrm{f}-\mathrm{g}$ ), a large continuous area located in central Rio de Janeiro, south of Minas Gerais areas; northeast central and coast of São Paulo, central and coastal Paraná and coast of Santa Catarina areas (Figure 2f); a second continuous area is in the coasts of Rio de Janeiro, Espírito Santo, Bahia, Sergipe, Alagoas, and Pernambuco (Figure 2g).

Overall, our comprehensive assessment using PAE and NDM recognized at least five main areas of endemism; most of them were identical across methods. These areas included: (a) Pernambuco and coastal Bahia 
a

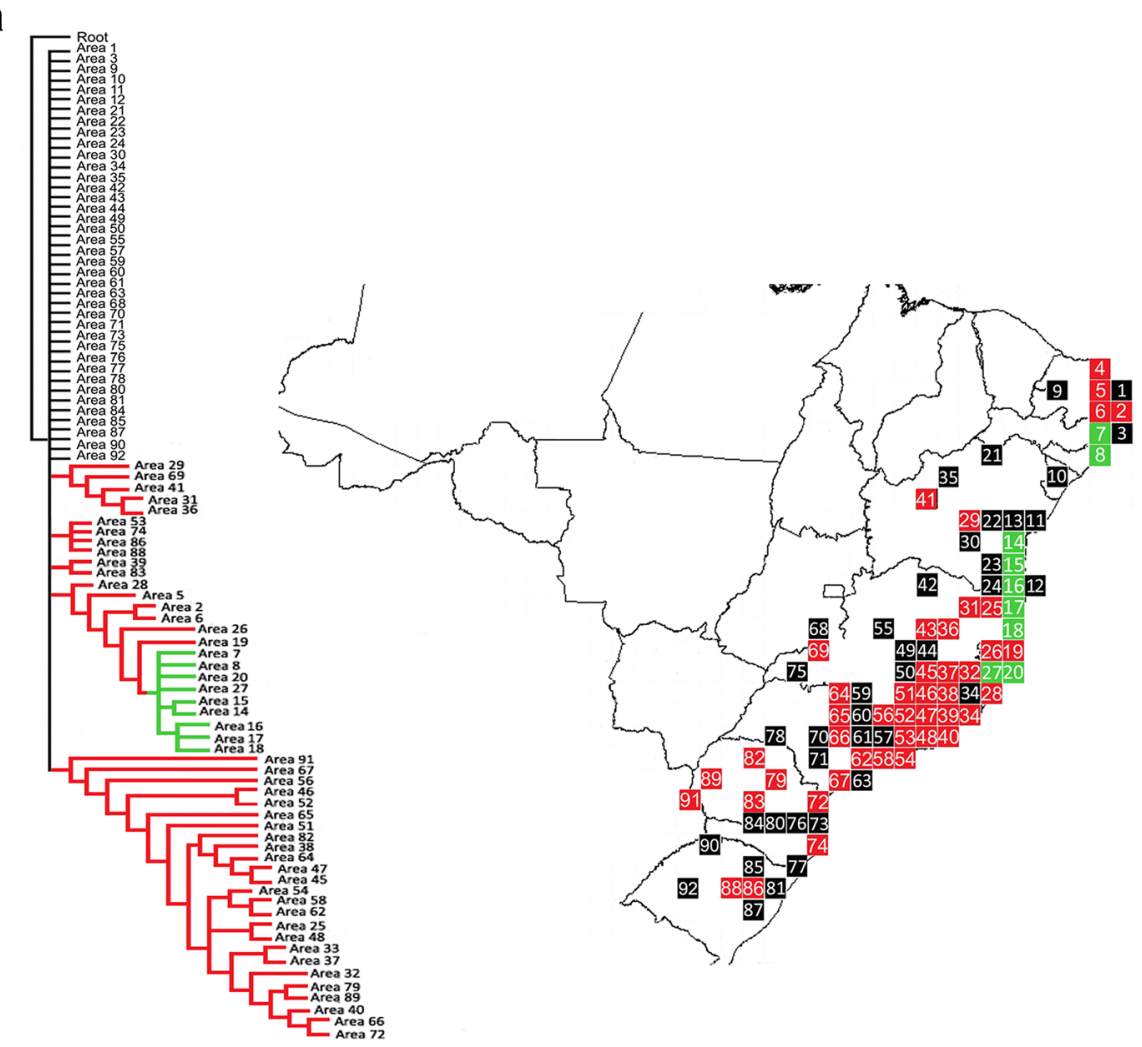

b

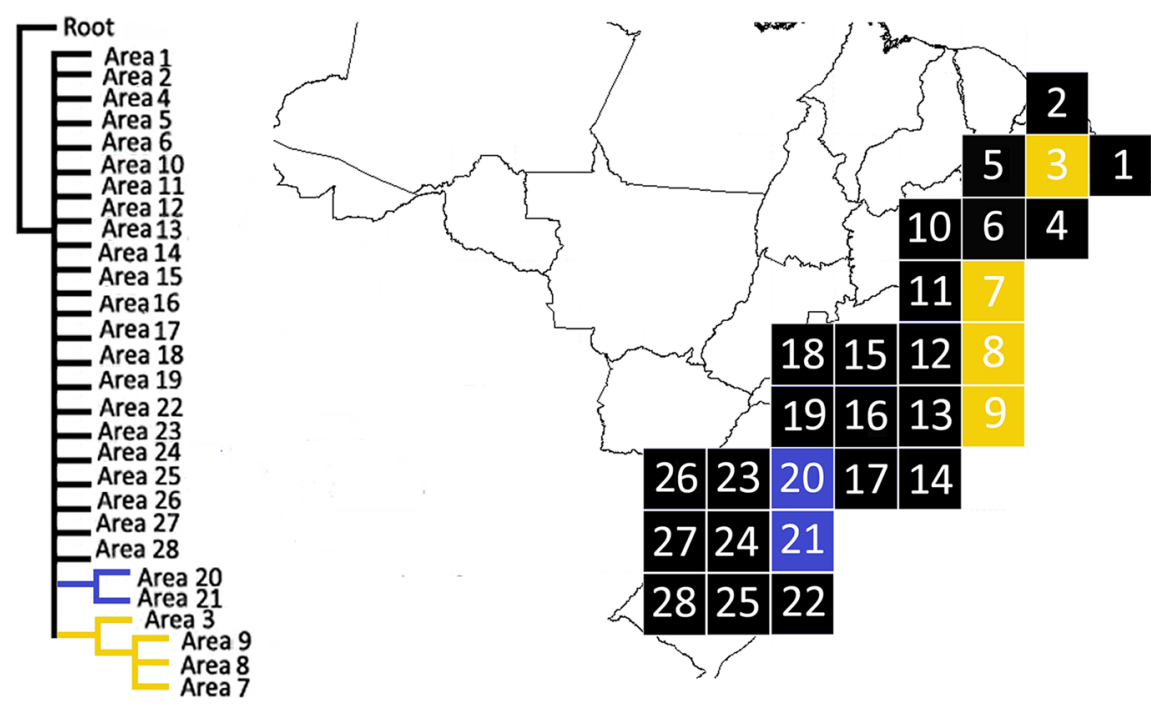

component; (b) Espírito Santo, Rio de Janeiro, and south of Minas Gerais component; (c) north of Minas Gerais and central Bahia component; (d) southeast of Minas Gerais, northeast and central of São Paulo, central Paraná, and coastal Paraná component; and 
Figure 1. Study area and strict consensus cladograms with grid-cells used for PAE analyses of orchid bees in the Atlantic Rain Forest. a $1 \times 1^{\circ}$ with grid-cells numbered from 1 to 92 ; b $3 \times 3^{\circ}$ with grid-cells numbered from 1 to 28. The colors red (in a) and blue (in b) indicate the resulting major clades that are composed of more than one grid-cell and supported by homoplasies or only one exclusive species; the colors green (in a) and yellow (in b ) indicate the resulting major clades that are composed of more than one grid-cell and are supported by two or more exclusive species; and the color black indicates that the grid-cell is not clustered.

(e) central and coast of the Santa Catarina-Rio Grande do Sul component (Figure 3).

\section{DISCUSSION}

In this study, we followed Amorim and Pires (1996) and accepted a priori that the Atlantic Forest subregion is a monophyletic biogeographic unit composed of northern and southern areas. However, we are aware that some authors have argued that the Atlantic Forest is non-monophyletic because the northern part of the Atlantic Forest is a sistergroup taxon of the Southeast Amazonia component (e.g., Nihei and de Carvalho, 2007). Notwithstanding the discussion regarding the monophyly of the Atlantic Forest as a biogeographic unit, it is the consensus that the Atlantic Forest is divided into two subregions (north and south) (Amorim and Pires 1996; Costa et al. 2000; Sydney et al. 2010; DaSilva and Pinto-da-Rocha 2011; López-Uribe et al. 2014; this analysis).

The biogeographic analyses presented here indicate the existence of five distinct areas of orchid bee endemism in the Atlantic Rain Forest. The large number of areas of endemism may be related to the strongly heterogeneous floristic and geological composition, climatic seasonality, and altitudinal zonation of the Atlantic Forest, even after 500 years of anthropogenic pressure, which has fragmented the forest and reduced its extent to less than $8 \%$ of the original area (Morellato and Haddad 2000). This fragmentation of the Atlantic Forest due to anthropogenic interference can have a direct effect on the richness and diversity of orchid bees (Nemésio 2013). Our results emphasize that
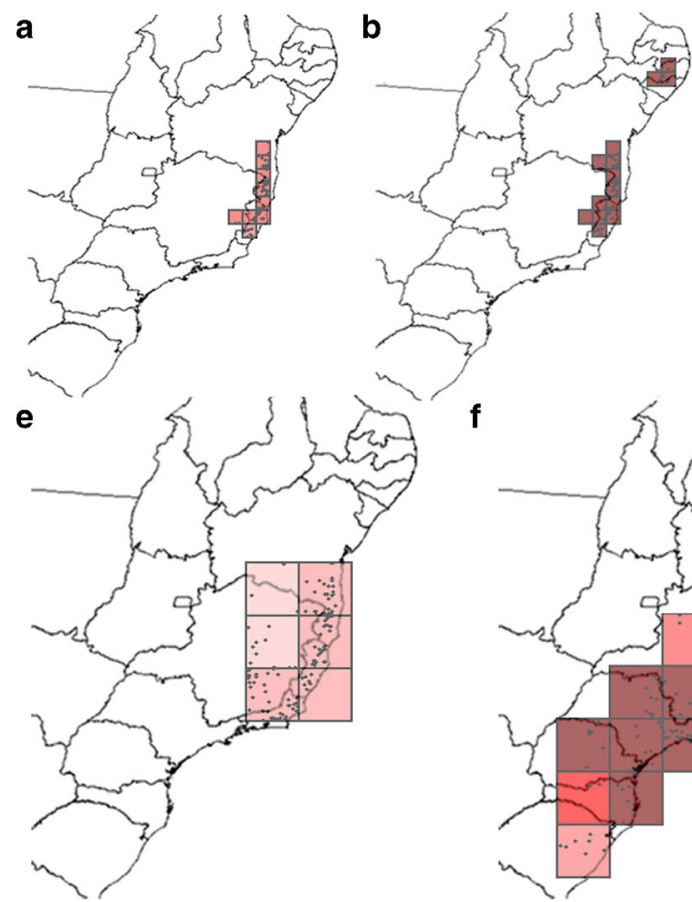

f

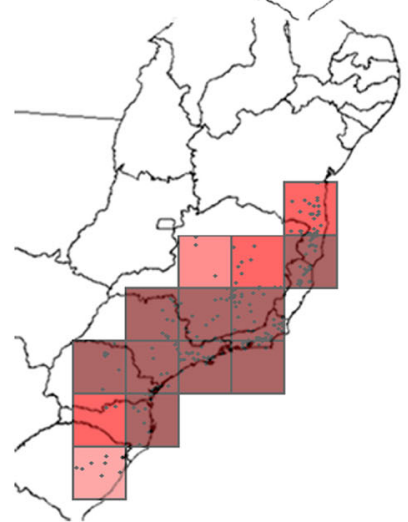

g
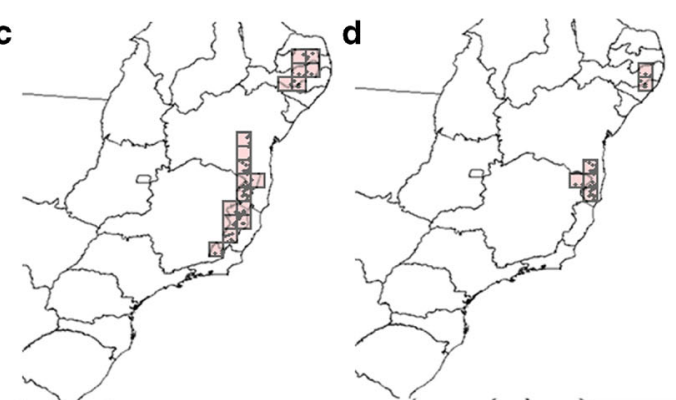

Figure 2. Consensus areas of endemism (shades of red) identified by NDM/VNDM using 1-degree grid-cells ( $a-$ $d$ ). Areas of endemism (shades of red) identified using 3-degree grid-cells $(e-g)$. 
Table I. Consensus areas of endemism identified by NDM/VNDM based on 1- and 3-degree grid-cells, as shown in Figure 2 (letters a-g)

\begin{tabular}{|c|c|c|c|}
\hline $\begin{array}{l}\text { Letter } \\
\text { (Figure 2) }\end{array}$ & $\begin{array}{l}\text { Number } \\
\text { of cells }\end{array}$ & $\begin{array}{l}\text { Number of } \\
\text { species }\end{array}$ & Species \\
\hline $\mathrm{a}$ & 9 & 8 & $\begin{array}{l}\text { Eg. adisastola, Eg. amazonica, Eg.augaspula, Eg. avicula, Eg. botocuda, } \\
\text { Eg. cognata, Eg. liopoda, Eg. pepei }\end{array}$ \\
\hline $\mathrm{b}$ & 14 & 9 & $\begin{array}{l}\text { Eg. amazonica, Eg. augaspis, Eg. calycina, Eg.clausi, Eg. milenae, Eg. } \\
\text { mixta, Eg. monnei, Eg.pepei, Ex. frontalis }\end{array}$ \\
\hline $\mathrm{c}$ & 18 & 3 & Eg.mixta, El.atleticana, El.niveofasciata \\
\hline d & 6 & 3 & Eg. adisastola, Eg. amazonica, Eg.pepei \\
\hline $\mathrm{e}$ & 6 & 11 & $\begin{array}{l}\text { Ef. atlantica, Ef. nigrohirta, Eg. augaspula, Eg. avicula, Eg. botocuda, } \\
\text { Eg. liopoda }, \text { Eg. sapphirina, Ex. salsai }\end{array}$ \\
\hline $\mathrm{f}$ & 20 & 30 & $\begin{array}{l}\text { Ef. atlantica, Ef. auriceps, Ef. nigrohirta, Eg. analis, Eg. cordata, Eg. } \\
\text { bembei, Eg. carinilabris, Eg. crassipunctata, Eg. despecta, Eg. } \\
\text { fimbriata, Eg. hemichlora, Eg. ignita, Eg. imperialis, Eg. iopoecila, Eg. } \\
\text { ioprosopa, Eg. leucotricha, Eg. marianae, Eg. melanotricha, Eg. } \\
\text { pleosticta, Eg. roderici, Eg. sapphirina, Eg. securigera, Eg. stellfeldi, } \\
\text { Eg.truncata, Eg. viridis, El.atleticana, El.nigrita, El.niveofasciata }, \text { Ex. } \\
\text { smaragdina }\end{array}$ \\
\hline $\mathrm{g}$ & 14 & 27 & $\begin{array}{l}\text { Ef. aeneiventris, Ef.atlantica, Ef. dentilabris, Ef. smaragdina, Eg. analis, } \\
\text { Eg. annectans, Eg. bembei, Eg. carinilabris, Eg. crassipunctata, Eg. } \\
\text { despecta }, \text { Eg. hemichlora, Eg. ignita, Eg. imperialis, Eg. iopoecila, Eg. } \\
\text { ioprosopa, Eg. leucotricha, Eg. mandibulata, Eg. marianae, Eg. } \\
\text { sapphirina, Eg. securigera, Eg. stellfeldi, Eg. viridis, El.atleticana, El. } \\
\text { helvola, El. niveofasciata, El. sebrai, Ex. dentata }\end{array}$ \\
\hline
\end{tabular}

Ef Eufriesea, Eg Euglossa, El Eulaema, Ex Exaerete

the impacts of isolation caused by fragmentation differ significantly among species and will affect the structure of different populations in different ways (Silveira et al. 2015). Some species with broad distributional patterns (such as El. cingulata, Euglossa imperialis, and Eg. truncata ) can also be sampled in forest remnants of the Brazilian savanna biome (Nemésio and Faria-Jr 2004; Viotti et al. 2013; Silveira et al. 2015; Antonini et al. 2016). By contrast, Eg . nanomelanotricha has shown a very narrow distribution, having been originally reported in the Brazilian state of Paraíba and later in the states of Sergipe, Pernambuco, Alagoas, and Piauí (Ferrari and Nemésio 2011). The same result is observed for Euglossa roderici, which is primarily found in coastal areas of São Paulo and Paraná (Nemésio 2009) and for Efriesea brasilianorum, Euglossa botucuda, and Euglossa cyanochlora which have only been reported in the Hileia Baiana forest (Nemésio
2009, 2012; Faria-Jr and Melo, 2007). Ef. brasilianorum and Eulaema felipei have been recorded at only one sampling point each, exhibiting the most limited distributions (respectively, northern of Espírito Santo state and northeast of Alagoas state). In other words, many euglossine species range across extensive geographic areas, but many others have distributions that are very limited, indicating that the Atlantic Forest is able to support a heterogeneous fauna of orchid bees. These different distribution patterns of orchid bees were noted by Nemésio and Silveira (2007) and can be tentatively explained by assuming that orchid bee species have the following characteristics: (a) distinct dispersal abilities due to distinct body sizes and (b) relatively recent origins (20 million years ago) (Dick et al. 2004).

If we compare these five predicted areas of endemism for orchid bees in the Atlantic Forest and for other animals with similar patterns of 


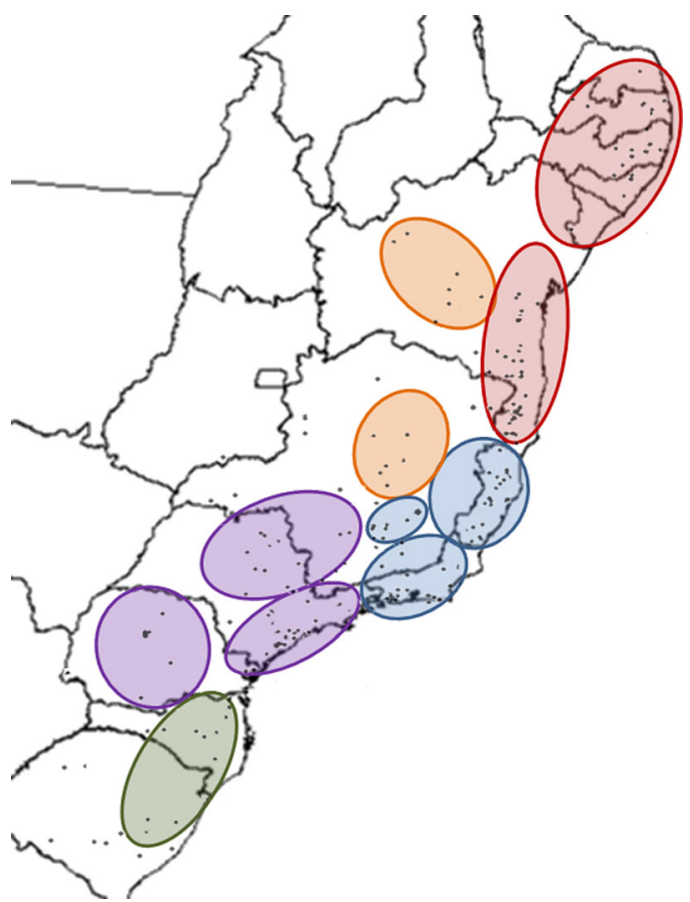

Figure 3. Diagrammatic representation of the boundaries of the five areas of endemism (one color corresponds to one area) identified for orchid bees in the Atlantic Forest plotted over the sampling sites. Red: Pernambuco and coastal Bahia component; blue: Espírito Santo, Rio de Janeiro, and south of Minas Gerais component; orange: north of Minas Gerais and central Bahia component; purple: southeast of Minas Gerais, northeast, central and coast of São Paulo, central and coastal Paraná component; and green : central and coast of Santa Catarina-Rio Grande do Sul component.

general distribution, we can observe at least one area of endemism (sometimes two or three) in the north and at least two areas (sometimes three) in the south (Amorim and Pires, 1996: primates and dipterans; da Silva et al. 2004: birds; Costa et al. 2000: mammals; Tyler et al. 1994: butterflies; Pinto-da-Rocha and DaSilva 2005: opiliones). The different numbers of areas of endemism identified by these studies may be due to the use of different grid-cell sizes, different diversification models for the animals used in each study, and the number of sampling sites (Sydney et al. 2010) because having a small number of surveys conducted in a region may erroneously increase the possible number of endemic species in that region or its subregions.
Hileia Baiana (southern Bahia and northern Espírito Santo) is considered one of the richest regions in the Atlantic Forest encompassing high levels of diversity and endemism (e.g., Thomas et al. 1998); this forest was not identified in our study as a distinct biogeographic component. Recently, Nemésio and Santos-Junior (2014) recorded euglossine species in the Pernambuco component ("Centro de Endemismo Pernambuco") that were endemic (Eg . carinilabris, Eg. monnei, Eg. pepei $)$ to the Hileia Baiana. The proximity of these two regions was also identified in our study. We also observed that the Hileia Baiana was split into at least two separate areas of endemism; the same pattern has been reported in other studies (Amorim and Pires 1996; Tyler et al. 1994; da Silva et al. 2004). The portion located in the state of Bahia is included in the north Atlantic Forest and the portion located in the state of Espírito Santo is part of the south Atlantic Forest.

Although it is not our intention to deeply evaluate and contrast the different methods we used here (for recent revisions about these problems see Oliveira et al. 2015 and DaSilva et al. 2015), we briefly mention some differences regarding the two numerical methods and the impact of the quadrats sizes as spatial units. Endemic components recovered in both analyses (PAE and NDM) were congruent and the observed slight differences occurred because the two methods applies different approaches: PAE requires complete congruence of species presence/ absence in the quadrats, whereas, NDM uses numerical criteria to relax this congruence (DaSilva 2008). The primary difference between the areas of endemism identified from the two analyses is directly related to the reported sampling efforts in southern and southeastern Brazil. The Paraná component (Müller 1973; Cracraft 1985) was not identified by PAE due to the low number of sampling sites in Santa Catarina and Rio Grande do Sul, whereas, the central Minas Gerais component was easily identified by NDM due to the intensive sampling efforts conducted by Nemésio and co-authors in the region. In the present study, PAE and NDM achieved a better resolution and a larger number of synapomorphies for the $3 \times 3^{\circ}$ grid-cells than those for the $1 \times 1^{\circ}$ grid-cells, as was also observed by Morrone and Escalante (2002) and da Silva (2008). The summarization of the five areas obtained in the 
present study was primarily based on the results of the NDM of $3 \times 3^{\circ}$ because this analysis shows a great flexibility in the recognition of spatial patterns, achieving a high success rate of recovery of the expected patterns (Casagranda and Taher 2007).

In conclusion, the results presented here are an initial step for a better understanding of the distributional patterns of orchid bees in the Atlantic Forest. Distinct quantitative biogeographic methods were used to pursue a better assessment of the primary biogeographic homology in one very peculiar Neotropical subregion. As the hypothesis of euglossine relationships has been improved and some clarifications have been done (Kimsey 1982, 1987; Michel-Salzat et al. 2004; Oliveira 2006; Ramirez et al. 2010), future studies can develop a cladistic test to assess the primary biogeographical homology recognized here (secondary biogeographical homology) or investigate these endemic areas of the bee fauna and its plant relationships (Kuhlmann 2009). Thus, we hope that these issues will encourage further research into the systematics and evolution of this important pollinator of many plant species in the Atlantic Forest.

\section{ACKNOWLEDGMENTS}

We are grateful to Dr. Silvio Nihei for valuable suggestions that improved the first draft of this manuscript, the Willi Hennig Society for subsidizing the TNT computer program and making it freely available. Two anonymous reviewers are also acknowledged for offering suggestions that greatly improved the paper.

Authors' contribution ARSG, FRM, and APL: designed the study; ARSG, FRM, and APL: collected and anlyzed the data; and ARSG and APL: wrote the paper.

Aires d'endémisme dans la Forêt atlantique: perspectives de biogéographie quantitative à partir des abeilles à orchidée (Apidae: Euglossini)

Brésil / schéma de distribution / insectes / analyse de parcimonie de l'endémicité / NDM

Gegenden mit Endemismus im Atlantischen Regenwald: quantitative biogeographische Erkenntnisse anhand von Prachtbienen (Apidae:Euglossini)

Brasilien / Verbreitungsmuster / Insekten / PAE / NDM

\section{REFERENCES}

Amorim, D.S., Pires, M.R.S. (1996) Neotropical biogeography and a method for maximum biodiversity estimation. In: Bicudo, C.E.M., Menezes, N.A. Menezes (eds.), Biodiversity in Brazil, a First Approach. CNPq, São Paulo, pp. 183-219

Antonini, Y., Silveira, R.A., Oliveira, M., Martins, C., Oliveira, R. (2016) Orchid bee fauna responds to habitat complexity on a savanna area (Cerrado) in Brazil. Sociobiology 63, 819-825

Carvalho, C.J.B. (2011) Áreas de endemismo. In: de Carvalho, C.J.B., Almeida, E.A.B. (eds.), Biogeografia da América do Sul - Padrões e Processos, Editora Roca, pp. 41-51

Casagranda, D., Taher, L. (2007) Elementos bióticos, endemismo y parsimonia: estudio de casos de distribuciones hipotéticas. Darwiniana 45, 37-38

Casagranda, M.D., Taher, L., Szumik, C.A. (2012) Endemicity analysis, parsimony and biotic elements: a formal comparison using hypothetical distributions. Cladistics 28, 645-654

Cockerell, T. D. A. (1908) Notes on the bee-genus Exaerete. Psyche 15, 41-42

Contreras-Medina, R., Vega, I.L., Morrone, J.J. (2007) Application of parsimony analysis of endemicity to Mexican gymnosperm distributions: grid-cells, biogeographical provinces and track analysis. Biol. J. Linnean. Soc. 92, 405-417

Costa, LP., Leite, Y.L.R., da Fonseca, G.A.B., da Fonseca, M.T. (2000) Biogeography of South American forest mammals: endemism and diversity in the Atlantic forest. Biotropica 32, 872-881

Cracraft, J. (1985) Historical biogeography and patterns of differentiation within the South America avifauna: areas of endemism. Ornithol. Monogr. $36,49-84$

da Silva, J.M.C., de Sousa, M.C., Castelletti, C.H.M. (2004) Areas of endemism for passerine birds in the Atlantic forest, South America. Global. Ecol. Biogeogr. 13, 85-92

DaSilva, M.B. (2008) Biogeografia de opiliões Gonyleptidae na Mata Atlântica, com revisão sistemática de Hernandariinae (Arachnida, Opiliones). PhD Thesis, University of São Paulo, São Paulo.

DaSilva M.B., Pinto-da-Rocha R. (2011) História biogeográfica da Mata Atlântica: opiliões (Arachnida) como modelo para sua inferência. In: de Carvalho, C.J.B., Almeida, E.A.B. (eds.), Biogeografia da América do Sul - Padrões e Processos, Editora Roca, pp. 221238

DaSilva, M. B., Pinto-da-Rocha, R., De Souza, A. M. (2015) A protocol for the delimitation of areas of endemism and the historical regionalization of the Brazilian Atlantic Rain Forest using harvestmen distribution data. Cladistics, 31, 692705 . 
Dick, C.W., Roubik, D.W., Gruber, K.F., Bermingham, E. (2004) Long-distance gene flow and cross-Andean dispersal of lowland rainforest bees (Apidae: Euglossini) revealed by comparative mitochondrial DNA phylogeography. Mol. Ecol. 13, 3775-3785

Escalante, T., Morrone, J.J., Rodríguez-Tapia, G. (2013) Biogeographic regions of North American mammals based on endemism. Biol. J. Linnean. Soc. 110, 485-499

Faria-Jr, L.R.R., Melo, G.A.R. (2007) Species of Euglossa (Glossura) in the Brazilian Atlantic forest, with taxonomic notes on Euglossa stellfeldi Moure (Hymenoptera, Apidae, Euglossina). Rev. Bras. Entomol. 51, 275-284

Ferrari, R., Nemésio, A. (2011) Description of the female Euglossa nanomelanotricha Nemésio, 2009. Spixiana 34, 221-224.

Ferrari, A., Paladini, A., Schwertner, C.F., Grazia, J. (2010) Endemism analysis of Neotropical Pentatomidae (Hemiptera, Heteroptera). Iheringia 100, 449-462

Goloboff, P. (2005). NDM/VNDM. Programs for identification of areas of endemism. http://www.zmuc. $\mathrm{dk} /$ public/phylogeny/endemism (accessed 15 August 2015)

Goloboff, P.A., Farris, J.S., Nixon, K.C. (2003) T.N.T.: tree analysis using new technology. http://www.zmuc. dk/public/phylogeny/tnt (accessed 15 August 2015)

Goloboff, P.A., Farris, J.S., Nixon, K.C. (2008) TNT, a free program for phylogenetic analysis. Cladistics 24, 774-786

Hoffmannsegg, J. C. (1817) Entomologische Bemerkunde bei Gelegenheite der Abhandlungen uber Amerikanische Insekten. Zool. Mag. Kiel 1, 8-56

Kimsey, L.S. (1982) Systematics of bees of the genus Eufriesea (Hymenoptera, Apidae). Univ. Calif. Publ. Entomol. 95, 1-125

Kimsey, L.S. (1987) Generic relationships within the Euglossini (Hymenoptera: Apidae). Sys. Entomol. $12,63-72$

Kuhlmann, M. (2009) Patterns of diversity, endemism and distribution of bees (Insecta: Hymenoptera: Anthophila) in southern Africa. S. Afr. J. Bot. 75, 726-738.

Latreille, P.A. (1802) Historie Naturelle, Generale et Particuliere des Crustaces et des Insectes. 14 volumes. F. Dufart. Paris

Lepeletier, A.L.M. (1841) Histoire Naturelle des Insectes, Hyménoptères, Vol. 2. Librairie Encyclopédique de Roret, Paris, 680 pp

Lepeletier, A. L. M. \& Serville, J. G. A. (1825) Encyclopedie Méthodique. Histoire Naturelle. Entomologie, ou Histoire Naturelle des Crustacés, des Arachnides et des Insectes. Vol. 10. Agasse, Paris, 344 pp

López-Uribe, M.M., Zamudio, K.R., Cardoso, C.F., Danforth, B.N. (2014) Climate, physiological tolerance and sex-biased dispersal shape genetic structure of Neotropical orchid bees. Mol. Ecol. 23, 1874-1890

Michel-Salzat, A., Cameron, S.A., Oliveira, M.L. (2004) Phylogeny of the orchid bees (Hymenoptera: Apinae: Euglossini): DNA and morphology yield equivalent patterns. Mol. Phylogenet. Evol. 32, 309-323
Michener, C.D. (2007) The bees of the world. Johns Hopkins University Press, Baltimore

Morellato, P.C., Haddad, C.F.B. (2000) Introduction: the Brazilian Atlantic forest. Biotropica 32, 786-792

Morrone, J.J. (1994) On the identification of areas of endemism. Syst. Biol. 43, 438-441

Morrone, J.J. (2001) Homology, biogeography and areas of endemism. Divers. Distrib. 7, 297-300

Morrone, J.J. (2014) Parsimony analysis of endemicity (PAE) revisited. J. Biogeogr. 41, 842-854

Morrone, J.J., Escalante, T. (2002) Parsimony analysis of endemicity (PAE) of Mexican terrestrial mammals at different areas units: when size matters. J. Biogeogr. 29, 1095-1104

Moure, J.S., Melo, G.A.R., Faria Jr., L.R.R. (2012) Euglossini Latreille, 1802. In Moure, J.S., Urban, D., Melo, G.A.R. (Orgs). Catalogue of bees (Hymenoptera, Apoidea) in the neotropical region-online version (accessed on 25 February 2016)

Müller, P. (1973) Dispersal centers of terrestrial vertebrates in the Neotropical realm: a study in the evolution of the Neotropical biota and its native landscape. Junk, Hague

Nemésio, A. (2009) Orchid bees (Hymenoptera: Apidae) of the Brazilian Atlantic Forest. Zootaxa 2041, 1-242

Nemésio, A. (2012) Species of the Euglossa Latreille, 1802 (Hymenoptera: Apidae: Euglossina) belonging to the purpurea species group occurring in eastern Brazil, with description of Euglossa monnei sp.n. Zootaxa 3151, 35-52

Nemésio, A. (2013) The orchid-bee faunas (Hymenoptera: Apidae) of "Parque Nacional do Monte Pascoal", "Parque Nacional do Descobrimento" and three other Atlantic Forest remnants in southern Bahia, eastern Brazil. Braz. J. Biol. 73, 437446

Nemésio, A., Faria-Jr L.R.R. (2004) First assessment of the orchid-bee fauna (Hymenoptera: Apidae) at Parque Estadual do Rio Preto, a Cerrado area in southeastern Brazil. Lundiana 5, 113-117

Nemésio, A., \& Santos-Junior, J. E. (2014). Is the "Centro de Endemismo Pernambuco" a biodiversity hotspot for orchid bees? Braz. J. Biol. 74, 78-92.

Nemésio, A., Silveira, F.A. (2007) Diversity and distribution of orchid bees (Hymenoptera: Apidae: Euglossina) with a revised checklist of their species. Neotrop. Entomol. 36, 874-888

Nemésio, A., Vasconcelos, H.L. (2013) Beta diversity of orchid bees in a tropical biodiversity hotspot. Biodivers. Conserv. 22, 1647-1661

Nihei, S.S. (2006) Misconceptions about parsimony analysis of endemicity. J. Biogeogr. 33, 2099-2106

Nihei, S.S., de Carvalho, C.J.B. (2007) Systematics and biogeography of Polietina Schnabl \& Dziedzicki (Diptera, Muscidae): neotropical areas relationships and Amazonia as a composite area. Syst. Entomol. 32, 477-501 
Nixon, K.C. (2002) WinClada ver. 1.00.08. Available at: http://www.cladistics.com/aboutWinc.htm (accessed on 15 August 2015)

Oliveira, M.L. (2006) Nova hipótese de relacionamento filogenético entre os gêneros de Euglossini e entre as espécies de Eulaema Lepeletier, 1841 (Hymenoptera: Apidae: Euglossini). Acta Amaz. 36, 273-286

Oliveira, U., Brescovit, A. D., Santos, A. J. (2015) Delimiting areas of endemism through kernel interpolation. PloS one 10, e0116673

Pinto-Da-Rocha, R., DaSilva, M.B. (2005) Faunistic similarity and historic biogeography of the harvestmen of southern and southeastern Atlantic Rain Forest of Brazil. J. Arachnology 33, 290-299

Ramírez, S.R., Roubik, D.W., Skov, C., Pierce, N.E. (2010) Phylogeny, diversification patterns and historical biogeography of euglossine orchid bees (Hymenoptera: Apidae). Biol. J. Linnean Soc. 100, 552-572

Rosen, B.R. (1988) From fossils to earth history: applied historical biogeography. In: Myers, A.A., Giller, P.S. (eds), Analytical biogeography: an integrated approach to the study of animal and plant distributions, Chapman \& Hall, London pp. 437-481

Rosen, B.R., Smith, A.B. (1988) Tectonics from fossils? Analysis of reef-coral and sea-urchin distributions from late Cretaceous to recent, using a new method. In: Audley-Charles, M.G., Hallam, A. (eds.), Gondwana and Tethy, Geological Society London Special Publication 37, pp. 275-306
Silveira, F.A., Melo, G.A.R., Almeida, E.A.B. (2002) Abelhas Brasileiras: Sistemática e Identificação. Published by the authors, Belo Horizonte

Silveira, G.C., Freitas, R.F., Tosta, T.H.A., Rabelo, L.S., Gaglianone, M., Augusto, S.C. (2015) The orchid bee fauna in the Brazilian savanna: do forest formations contribute to higher species diversity? Apidologie 46, 197-208

Sydney, N.V., Gonçalves, R.B., Faria-Jr, L.R.R. (2010) Padrões espaciais na distribuição de abelhas Euglossina (Hymenoptera, Apidae) da região Neotropical. Pap. Avulsos Zool. 50, 667-679

Szumik, C.A., Goloboff, P.A. (2004) Areas of endemism: an improved optimality criterion. Syst. Biol. 53, 968-977

Szumik, C.A., Cuezzo, F., Goloboff, P.A., Chalup, A.E. (2002) An optimality criterion to determine areas of endemism. Syst. Biol. 51, 806-816

Tyler, H.A., Brown-JR, K.S., Wilson, K.H. (1994) Swallowtail butterflies of the Americas: a study in biological dynamics, ecological diversity, biosystematics, and conservation. Scientific Publishers, Gainesville

Viotti, M.A., Moura, F.R., Lourenço, A.P. (2013) Species diversity and temporal variation of the orchid-bee fauna (Hymenoptera, Apidae) in a conservation gradient of a rocky field area in the Espinhaço range, state of Minas Gerais, southeastern Brazil. Neotrop. Entomol. 42, 565-575 